\title{
Doses of Crotalaria juncea: Residual effect on zucchini and maize crop in sequence to broccoli ${ }^{1}$
}

\author{
Ellen Rúbia Diniz², Thiago de O Vargas $^{3 *}$, Amanda F Guedes ${ }^{4}$, Ricardo Henrique Silva Santos ${ }^{4}$, \\ Segundo Urquiaga ${ }^{5}$, Alcir José Modolo ${ }^{3}$
}

10.1590/0034-737X201764060006

\begin{abstract}
Amounts of $\mathrm{N}$ from green manures not absorbed in the first cycle can be absorbed by the subsequent crops. Therefore, it is important to quantify and monitor the residual effects of green manure to increase the agronomic benefits of its use in cropping systems. Our purpose was to study the residual effect of doses of the Crotalaria juncea green manure applied in broccoli crop in the zucchini-maize succession. This study was carried out in a crop succession system organized in three crops, with seven treatments and four major doses of green manure as $0,3,6$, and $9 \mathrm{tha}^{-1}$. The control treatments consisted of a mineral fertilization, a treatment with $25 \mathrm{t} \mathrm{ha}^{-1}$ compost, and another as absolute control without organic compost or mineral fertilizer. The experimental plot consisted of five rows spaced $0.8 \mathrm{~m}$ with $3 \mathrm{~m}$ in length. The experimental design was a completely randomized block with four replications in a split-plot scheme in time for growth with variables of adjustment of statistical models by the response surface methodology. With the highest dose of green manure, the yield of zucchini plants was greater than the yield with $25 \mathrm{tha}^{-1}$ compost control and similar with mineral fertilizer. As for the maize yield in the dose of $9 \mathrm{t} \mathrm{ha}^{-1}$ green manure, the yield was superior only to absolute control. There was a residual effect of $C$. juncea mass, which was applied in broccoli crop for growth and yield of zucchini and maize grown in succession. The residual effect is dependent on the amount of weight of $C$. juncea applied, with the greatest effects in larger doses.
\end{abstract}

Key words: Brassica oleracea var. italica; Cucurbita pepo; Zea mays; succeeding crops; green manure; nitrogen.

\section{RESUMO}

\section{Doses de Crotalaria juncea: Efeito residual no cultivo de abobrinha e milho em sequência ao brócolis}

Quantidades de N proveniente de adubos verdes não absorvidas no primeiro ciclo de cultivo, podem ser absorvidas em cultivos subsequentes. Portanto, é importante quantificar e monitorar o efeito residual da adubação verde visando aumentar o seu benefício agronômico nos sistemas de cultivos. O objetivo do trabalho foi estudar o efeito residual das doses do adubo verde Crotalaria juncea aplicadas no cultivo de brócolis, sobre a sucessão abobrinha italiana-milho. O estudo foi realizado em um sistema de sucessão de culturas organizado em três cultivos, com sete tratamentos, sendo os principais quatro doses de adubo verde: $0,3,6 \mathrm{e} 9 \mathrm{t} \mathrm{ha}^{-1}$. Os tratamentos testemunhas consistiram de adubação mineral, um tratamento com $25 \mathrm{tha}^{-1}$ de composto e um outro como testemunha absoluta, sem composto ou adubação mineral. A parcela experimental constou de cinco linhas espaçadas de $0,8 \mathrm{~m}$ com $3 \mathrm{~m}$ de comprimento. O delineamento experimental foi de blocos casualizados com quatro repetições no esquema de parcelas subdivididas no tempo para as

\footnotetext{
Submitted on February $15^{\text {th }}, 2016$ and accepted on October 02 $2^{\text {nd }}, 2017$.

${ }^{1}$ This work is part of the first author's doctoral thesis.

2Instituto Federal do Paraná, Ivaiporã, Paraná, Brasil. ellen.diniz@ifpr.edu.br

3nniversidade Tecnológica Federal do Paraná, Departamento de Ciências Agrárias, Pato Branco, Paraná, Brasil. thiagovargas@utfpr.edu.br; alcir@utfpr.edu.br

${ }^{4}$ Universidade Federal de Viçosa, Departamento de Fitotecnia, Viçosa, Minas Gerais, Brasil. manda_ufv@yahoo.com.br; rsantos@ufv.br

${ }_{5}^{5}$ Embrapa Agrobiologia, Seropédica, Rio Janeiro, Brasil. segundo.urquiaga@embrapa.br

Autor para correspondência: thiagovargas@utfpr.edu.br
}

Rev. Ceres, Viçosa, v. 64, n.6, p. 600-606, nov/dez, 2017 
variáveis de crescimento com ajuste dos modelos estatísticos pela metodologia de superfície de resposta. A produção das plantas de abobrinha na maior dose de adubo verde foi superior à produção das plantas na testemunha com $25 \mathrm{tha}$ ${ }^{1}$ de composto e similar com adubação mineral. A produtividade de milho na dose de $9 \mathrm{t} \mathrm{ha}^{-1}$ de adubo verde foi superior somente à produção da testemunha absoluta. Houve efeito residual da massa Crotalaria juncea, aplicada na cultura do brócolis, sobre o crescimento e a produção de abobrinha e produtividade do milho cultivados em sucessão. O efeito residual é dependente da quantidade de massa de Crotalaria juncea aplicada, com os maiores efeitos nas maiores doses.

Palavras-chave: Brassica oleracea var. italica; Cucurbita pepo; Zea mays; sucessão de culturas; adubação verde; nitrogênio.

\section{INTRODUCTION}

Legumes, when used as green manure (GM), besides adding $\mathrm{N}$ via biological nitrogen fixation (BNF), work in cycling $\mathrm{N}$ and other nutrients, concentrating them in the upper layers of the soil (Silva et al., 2002; Perin et al., 2010) and providing them to the crops (Vilela et al., 2011). However, the recovery of $\mathrm{N}$ in the GM crop is low. The percentage of $\mathrm{N}$ derived from BNF that is absorbed by crops varies from 12.45 to $22.9 \%$ of the total N (Castro et al., 2004; Silva et al., 2006; Diniz et al., 2007) and about $20 \%$ of the total N applied as GM (Scivittaro et al., 2003), while the efficiency of soluble mineral $\mathrm{N}$ varies between 26 and 61\% (Figueiredo et al., 2005; Alves et al., 2006; Lange et al., 2008). Therefore, the efficiency of GM to provide $\mathrm{N}$ is lower than the efficiency of soluble mineral $\mathrm{N}$.

However, regardless of the fertilizer source, the primary destination of $\mathrm{N}$ not absorbed by the plants is the soil in which it remains trapped in the surface layer, making it unavailable to the crops. This temporary unavailability may be due to the temporary immobilization of nutrients or incorporation into organic forms in soil organic matter (Scivittaro et al., 2003).

The potential of mineralization and immobilization of legume- $\mathrm{N}$ in the soil for seven weeks resulted in increased mineralization in the first week, followed by negative mineralization due to immobilization of $\mathrm{N}$, which prevailed especially until the third or fifth week, followed by a new positive mineralization and availability to crops (Matos et al., 2008).

In the immobilization period of $\mathrm{N}$, it becomes essential to supply one additional N source to crops. In the literature, there are studies with GM as well as GM in combination with additional sources of nutrients such as manure, poultry litter, or organic compost (Oliveira et al., 2003; Oliveira et al., 2005; Diniz et al., 2007). In such works, the total amount of $\mathrm{N}$ added by all sources was higher than those recommended for crops.
Those results suggest a possible residual effect of GM, which could be evidenced in sequential crops in the same area without subsequent fertilization. However, this has not been considered in most studies with GM. In shortcycle crops such as vegetable crops, only a part of the $\mathrm{N}$ derived from GM can be considered available in the short term for the N supply (Diniz et al., 2014; Katroschan et al., 2014).

Nitrogen quantities not absorbed in the first cycle of the crop can be absorbed by subsequent crops. Therefore, it is important to quantify and monitor the residual effects of GM to increase the agronomic benefits of its use in cropping systems. Our aim was to study the residual effect of doses of the Crotalaria juncea GM applied in broccoli crop for the Italian zucchini-maize succession.

\section{MATERIAL AND METHODS}

The study was conducted in Viçosa - MG, Brazil, located at $20^{\circ} 45^{\prime} 14^{\prime \prime} \mathrm{S}, 42^{\circ} 52^{\prime} 53^{\prime \prime} \mathrm{W}$, and $650 \mathrm{~m}$ altitude. The region has cold and dry winter as well as hot and rainy summer, with an average temperature of $19.4^{\circ} \mathrm{C}$ (maximum $26.4^{\circ} \mathrm{C}$ and minimum $14.8^{\circ} \mathrm{C}$ ) and average rainfall of 1,221 mm year ${ }^{-1}$.

The study on the residual effect of $\mathrm{N}$ from GM was carried out in a crop succession system organized in three crops. The first crop consisted of broccoli; the second and third crops consisted of Italian zucchini and maize, respectively, in the same plot without fertilization. The broccoli was grown in the period from March 26, 2010 to June 16, 2010 and after the harvest, the crop residues were left in the area and chopped into their respective terms. Chemical analysis of the soil, before growing broccoli, presented the following results: $24 \mathrm{~g} \mathrm{~kg}^{-1}$ organic matter (Walkley-Black), $\mathrm{pH}$ in water (1:2.5) $6.5,7 \mathrm{mg} \mathrm{dm}^{-3} \mathrm{P}$ (Mehlich I), $96 \mathrm{mg} \mathrm{dm}^{-3} \mathrm{~K}$ (Mehlich I), $2.70 \mathrm{cmolc} \mathrm{dm}^{-3} \mathrm{Ca}$, $0.40 \mathrm{cmolc} \mathrm{dm}^{-3} \mathrm{Mg}$, and $0.00 \mathrm{cmolc} \mathrm{dm}^{-3} \mathrm{Al}(\mathrm{KCl} 1 \mathrm{M})$.

Seven treatments have been established in the broccoli crop: four major and three controls. The main treatments 
consisted of four doses of GM: $0,3,6$, and $9 \mathrm{tha}^{-1}$ on a dry matter (DM) basis, with addition of $12 \mathrm{t} \mathrm{ha}^{-1}$ organic compost (OC) on a DM basis (0GM+12OC, 3GM+12OC, $6 \mathrm{GM}+12 \mathrm{OC}, 9 \mathrm{GM}+12 \mathrm{OC}$ ), according to Diniz et al. (2008). The control treatments consisted of a treatment with mineral fertilization (MF), a treatment with $25 \mathrm{t} \mathrm{ha}^{-1}$ compost on a DM basis (25OC), according to Diniz et al. (2008), and another as absolute control without organic compost or mineral fertilizer (AB). The experimental plot consisted of five rows spaced $0.8 \mathrm{~m}$ with $3 \mathrm{~m}$ in length. Green manure was applied on the surface on the day of transplanting broccoli. After the broccoli crop transplantation, no other source of nutrients for subsequent crops was added.

The OC, as source material elephant grass and poultry litter in 3:1 ratio (v:v), was produced on-site and applied to the planting furrows once before broccoli transplanting. Chemical analysis of the OC showed: $1.73 \% \mathrm{~N}, 0.83 \% \mathrm{P}$, $0.40 \% \mathrm{~K}, 2.12 \% \mathrm{Ca}, 0.35 \% \mathrm{Mg}, 0.63 \% \mathrm{~S}$, and $\mathrm{C} / \mathrm{N}=10.63$. The green manure was applied in the plots after transplanting the broccoli, without incorporation. The biochemical composition of sunn hemp had average contents of $\mathrm{N}=1.89 \%$, polyphenols $=1.56 \%$, lignin $=$ $11.89 \%$, cellulose $=39.39 \%, \mathrm{C} / \mathrm{N}=26.55$, lignin $/ \mathrm{N}=6.29$, polyphenols $/ \mathrm{N}=0.84$, and lignin/polyphenols $=7.62$. According to Tedesco et al. (1995), the total contents were determined in the acid extract and total carbon was calculated from the total content of organic matter determined by the loss of ignition method. The polyphenols were extracted with $50 \%$ methanol and determined colorimetrically using Folin-Denis reagent (Frighetto \& Valarini, 2000). The contents of cellulose and lignin were obtained via acid detergent fiber from the plant material by boiling sulfuric acid solution of $0.5 \mathrm{~mol} \mathrm{~L} \mathrm{~L}^{-1}$ plus cetyltrimethylammonium bromide. Nitrogen mineral fertilization control was applied to the broccoli at a dose of $150 \mathrm{~kg}$ ha" ${ }^{1} \mathrm{~N}$, which corresponds to $100 \%$ of the recommended dose of $\mathrm{N}$.

On July 20, 2010, the "Caserta” Italian zucchini crop was sown in polystyrene trays and was transplanted onto the field on 9 August 2010 with spacing of $0.8 \mathrm{~m}$ between rows and $0.6 \mathrm{~m}$ between plants. The zucchini growth was evaluated by weight accumulation of DM of shoot over the cycle until harvest, with one plant per plot sampled every 15 days. The fruit harvest period was from September 21,2010 , to October 6, 2010. In the last harvest of fruits, the shoot of the plants were collected and separated in the following parts: leaf blade, petiole, stem, and fruit. The samples were dried in a forced-air oven at $70{ }^{\circ} \mathrm{C}$ until constant mass and were weighted and grinded after drying.

The relative growth rate of the plants was calculated by the following equation:

$\operatorname{RGR}\left(\mathrm{g} \mathrm{g}^{-1} 15\right.$ days $\left.^{-1}\right)=\frac{\left(\ln \mathrm{M}_{2}-\ln \mathrm{M}_{1}\right)}{\left(t_{2}-t_{1}\right)}$ in which $\ln \mathrm{M}_{2}=$ Neperian logarithm of the mass in grams of the plant in the second sample, $\ln M_{1}=$ Neperian logarithm of the mass in grams of the plant in the first sampling (previous sampling), and $t_{2}$ and $t_{1}=15$ days between two samples.

The absolute growth rate was calculated by the following equation:

$\operatorname{AGR}\left(\mathrm{g} 15\right.$ days $\left.^{-1}\right)=\frac{\left(\mathrm{M}_{2}-\mathrm{M}_{1}\right)}{\left(t_{2}-t_{1}\right)}$

in which $\mathrm{M}_{2}=$ mass in grams of the plant in the second sample, $M_{1}=$ mass in grams of the plant in the first sampling (previous sampling), and $t_{2}$ and $t_{1}=15$ days between two samples.

The yield of zucchini was determined by the fresh weight of the harvested fruits with $1.5 \mathrm{~cm}$ of floral stalk throughout the yield period of four plants per plot. After oven-drying, the samples of the parts of the zucchini plants were weighed and ground. The $\mathrm{N}$ content was determined by the Kjeldahl method. From the total $\mathrm{N}$ content, the $\mathrm{N}$ accumulation in the plant parts and the proportion of $\mathrm{N}$ corresponding to each part in relation to the plant were calculated.

After the cultivation of zucchini, hybrid maize AG 1051 was planted on October 25, 2010 with $0.8 \mathrm{~m}$ space between rows and five seeds per meter; maize was planted on the same plots without any fertilization. The yield of DM of shoot, stem, leaves, tassel, and stalk with straw was determined during the physiological maturation of seeds, in two plants in the useful area of the plot. The yield was determined by the total grain weight per useful plot of 1.6 $\times 1.5 \mathrm{~m}$, yield data expressed per hectare, with the grain moisture corrected to $13 \%$.

The experimental design was a completely randomized block with four replications in a split-plot scheme in time for growth with variables of adjustment of statistical models by the response surface methodology. Data were evaluated by the analysis of variance by $\mathrm{F}$ test, the treatment means were compared to the controls using Dunnett's test, and regression to the effect of GM doses $(\mathrm{p}<0.05)$. The analyses were performed with the System for Statistical Analyses and Genetics, SAEG version 9.1.

\section{RESULTS AND DISCUSSION}

The main hypothesis that the nitrogen remaining in the soil and in the residues of green manure doses applied to broccoli (first cash crop) can be profitably used for growing other cash crops in close sequence (residual $\mathrm{N}$ effect) was confirmed. In short, broccoli production increased linearly with the increase of green manure dose. Here we describe the residual effect left by the application of $C$. juncea doses in the previous crop (broccoli) in zucchini-maize succession. 
The growth of Italian zucchini plants was positively influenced by the residual effect of GM doses days after transplanting (Figure 1). The DM was greater in plants with implementation of the largest GM dose and was increased as the days passed on after transplanting.

The comparison between the GM doses indicates that the relative growth rate was higher in doses of 6 and $9 \mathrm{t} \mathrm{ha}^{-1}$ in the first 15 days after transplanting. Over time, the zucchini plants grown on the residue of doses of 6 and $9 \mathrm{t} \mathrm{ha}^{-1} \mathrm{GM}$ also accumulated more DM up to 60 days, whose result was evidenced by higher values of the absolute growth rate. The period in which the plants showed higher relative growth rates was between 15 and 30 days. Zucchini plants accumulated more mass as the doses of GM that were previously applied in broccoli increased. The absolute growth rate, in the same week, was higher as this GM dose increased (Table 1).

There were significant effects of treatments on yield of Italian zucchini fruit (Table 2). The yield of plants that were treated with the previous application of GM was higher than the output of absolute control plants. The yield of plants with the highest dose of GM was higher than the yield of the plants in the control with $25 \mathrm{tha}^{-1}$ compost and similar to the plant yield with mineral fertilizer. With doses of 0,3 , and $6 \mathrm{t} \mathrm{ha}^{-1}$, the plant yield was lower than that obtained with mineral fertilizer and similar to that observed with $25 \mathrm{t} \mathrm{ha}^{-1}$ compost, both applied in the previous broccoli crop.
The lower residual effect of the organic compost may be related to the slow decomposition of the organic matter. According to Marchi et al. (2008), the predominance of humic acid carbon on fulvic acid carbon means a higher contribution of carbon to soil and lower nutrient mineralization, which might explain the low residual effect of the organic compost at a dose of $25 \mathrm{t} \mathrm{ha}^{-1}$ on the productivity of zucchini.

Both the GM at a dose of $9 \mathrm{t} \mathrm{ha}^{-1}$ and the mineral fertilization presented residual effect on yield of zucchini. There are few studies that evaluated the residual legume-N effect for two consecutive crop cycles. Vargas et al. (2011), working with the precrops Crotalaria juncea and Canavalia ensiformis GM, concluded that the need for mineral- $\mathrm{N}$ fertilizer can be reduced to $50 \%$ in the first cabbage crop. For a second crop, the authors concluded that the areas with green manure resulted in higher residual effect over areas with $100 \%$ of mineral-N fertilizer.

The yield of zucchini fruit grown in plastic tunnels with different crop management ranged from 390 to 463.6 g plant ${ }^{1}$ (Lúcio et al., 2008). In Sao Paulo, the average productivity in 2006 was 14.23 t ha $^{-1}$ (Camargo Filho \& Camargo, 2008). In the present study, the productivity of Italian zucchini with the highest dose of GM was $14.96 \mathrm{tha}^{-1}$ and in mineral fertilization it was $15.51 \mathrm{t} \mathrm{ha}^{-1}$, values similar to those of commercial crops.

$D M=-5.495+0.474667 D+0.455975 T R^{2}=0.81$

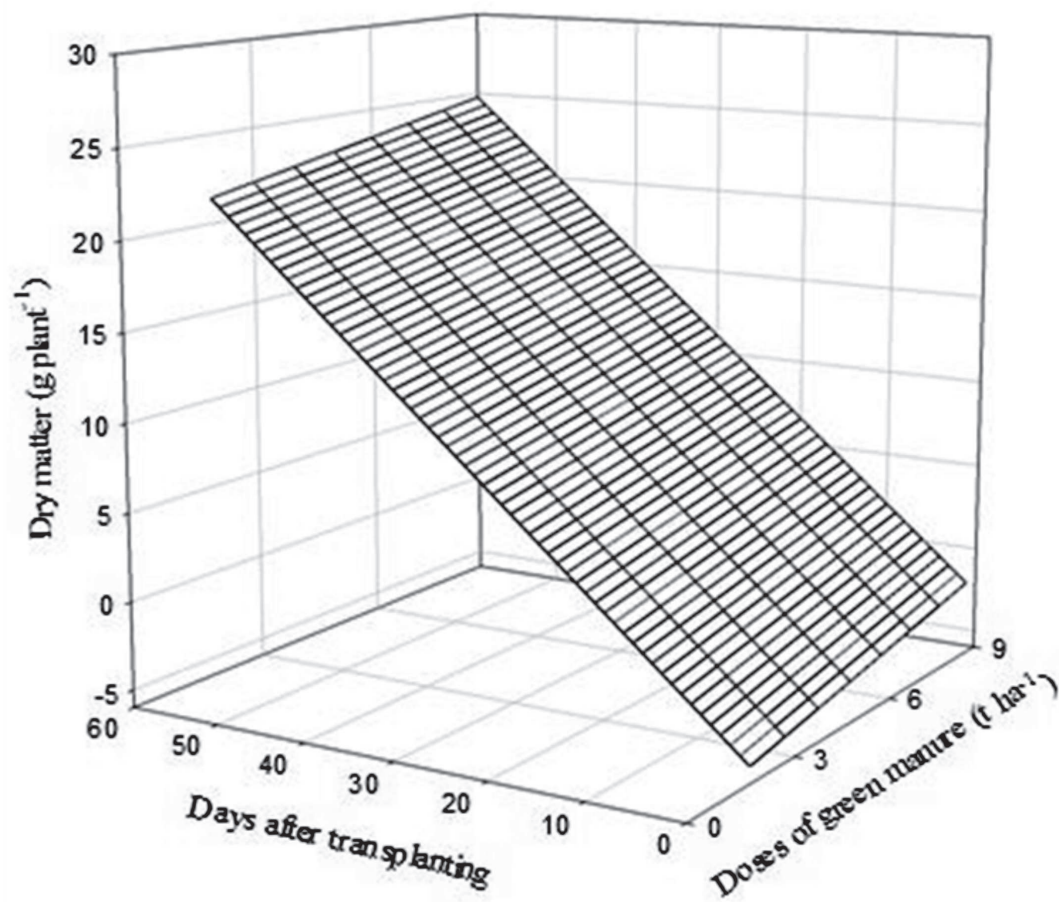

Figure 1. Residual effect of GM doses (D) and days after transplanting (T) on the dry matter (DM) of Italian zucchini plants cultivated in the Italian-broccoli zucchini succession. 
Table 1: Relative growth rate (RGR) in $\mathrm{g} \mathrm{g}^{-1} 15$ days $^{-1}$ and absolute growth rate (AGR) in $\mathrm{g} 15$ days $\mathrm{s}^{-1} \mathrm{~g}$ per plant, calculated from the dry matter of zucchini plants, measured every 15 days after transplanting to 60 days in zucchini plants grown with different GM doses

\begin{tabular}{|c|c|c|c|c|c|c|c|c|}
\hline \multirow{3}{*}{$\begin{array}{l}\text { Period } \\
\text { (days) }\end{array}$} & \multicolumn{8}{|c|}{ Doses of green manure ( $\left.t^{h a^{-1}}\right)$} \\
\hline & \multicolumn{2}{|c|}{$\mathbf{0}$} & \multicolumn{2}{|c|}{3} & \multicolumn{2}{|c|}{6} & \multicolumn{2}{|c|}{9} \\
\hline & RGR & AGR & RGR & AGR & RGR & AGR & RGR & AGR \\
\hline $0-15$ & 0.66 & 0.36 & 0.62 & 0.33 & 0.96 & 0.61 & 0.95 & 0.60 \\
\hline $15-30$ & 1.97 & 4.52 & 2.30 & 6.30 & 2.23 & 8.14 & 2.34 & 9.15 \\
\hline $30-45$ & 1.01 & 9.13 & 0.79 & 8.50 & 0.62 & 7.88 & 0.66 & 9.50 \\
\hline $45-60$ & 0.28 & 4.65 & 0.52 & 10.50 & 0.50 & 11.00 & 0.51 & 13.20 \\
\hline
\end{tabular}

Table 2: Mean values of zucchini yield and maize yield

\begin{tabular}{lcc}
\hline \multirow{2}{*}{ Treatments } & Zucchini & Maize \\
\cline { 2 - 3 } & (g plant") & (kg ha") \\
\hline AB & 139.01 & 2027.60 \\
25 OC & 376.00 & 3259.89 \\
MF & 679.61 & 3006.25 \\
\hline OGM + 120C & $319.81^{3}$ & 2200.52 \\
3GM + 120C & $403.06^{1.3}$ & 2296.87 \\
6GM + 120C & $443.91^{1.3}$ & 2603.12 \\
9GM + 120C & $655.21^{1.2}$ & $3998.95^{1}$ \\
\hline DMS & 191.79 & 1318.86 \\
CV $(\%)$ & 25.37 & 27.14 \\
\hline
\end{tabular}

Means followed by 1,2 , or 3 differ from $\mathrm{AB}, 25 \mathrm{OC}$, and $\mathrm{MF}$, respectively, by the Dunnett test $(\mathrm{p}<0.05)$.

$\mathrm{AB}$ - absolute control; 25OC - $25 \mathrm{t} \mathrm{ha}^{-1}$ compost; $\mathrm{MF}$ - mineral fertilizer; $0 \mathrm{GM}+12 \mathrm{OC}-$ dose $0 \mathrm{t} \mathrm{ha}^{-1}$ green manure $+12 \mathrm{t} \mathrm{ha}^{-1}$ compost; $3 \mathrm{GM}+12 \mathrm{OC}-$ dose $3 \mathrm{t} \mathrm{ha}^{-1}$ green manure $+12 \mathrm{t} \mathrm{ha}^{-1}$ compost; $6 \mathrm{GM}+12 \mathrm{OC}-$ dose $6 \mathrm{t} \mathrm{ha}^{-1}$ green manure $+12 \mathrm{t} \mathrm{ha}^{-1}$ compost; $9 \mathrm{GM}+12 \mathrm{OC}-$ dose $9 \mathrm{tha}^{-1}$ green manure $+12 \mathrm{tha}^{-1}$ compost.

The production of Italian zucchini fruits increased linearly with increasing GM doses in the previous crop, reaching $612.56 \mathrm{~g}$ plant $^{-1}$ with a dose of $9 \mathrm{t} \mathrm{ha}^{-1}$, which is equivalent to $13.98 \mathrm{t} \mathrm{ha}^{-1}$ (Figure 2A).

Even with a higher quantity of $\mathrm{N}$ applied to the plants for the treatment with $25 \mathrm{t} \mathrm{ha}^{-1}$ compost than in plants receiving the dose of $9 \mathrm{t} \mathrm{ha}^{-1} \mathrm{GM}$ plus compost, GM treatment had a greater residual effect (Table 3). The result suggests that the addition of combination of more GM plus compost may be highly advantageous than the use of organic compost alone because it results in a greater recovery of the $\mathrm{N}$ of the total amount applied. Research results show that after the incorporation of GM at the start of the growth of broccoli crop, it replaces $50 \%$ of the dose of the compost (Diniz et al., 2007).

There was residual effect both from GM and mineral fertilizers because even without the application of fertilizer in the cultivation of zucchini, the plant yield with the highest dose of GM and plants grown with mineral fertilizer were similar.
Without counting the losses of $\mathrm{N}$ in the soil-plantatmosphere system, which were not evaluated after the zucchini crop, the equivalent to $84.2 \%$ of the $\mathrm{N}$ applied initially in the treatments with GM doses and $45.4 \%$ of $\mathrm{N}$ applied to the plants that received mineral fertilizer (Table 3) still remained on average.

It is likely that the strength and durability of the residual effect of GM for crops depend not only on the chemical and biochemical composition of the material, but also on the amount of $\mathrm{N}$ applied. Associated with these factors, the elapsed time for the application of GM can possibly influence the formation of more recalcitrant $\mathrm{N}$ compounds in the soil (Matos et al., 2008) because by subtracting the amounts of $\mathrm{N}$ exported from those applied in this experiment, a range of about 45 to $90 \%$ of $\mathrm{N}$ still remained at the end of the zucchini crop (Table 3).

There was no effect of the control treatments or the green fertilizer doses on DM accumulation of maize and, on average, the plants accumulated $5373.1 \mathrm{~kg} \mathrm{ha}^{-1} \mathrm{DM}$. However, there were effects of treatment on the yield of maize (Table 2). The productivity of maize plants in the dose of $9 \mathrm{tha}^{-1} \mathrm{GM}$ was superior only to the yield of plants in the absolute control treatment. The yield of plants produced with $25 \mathrm{tha}^{-1}$ compost and mineral fertilizer was similar to the yield of plants produced with any dose of GM. This result is likely due to the low availability of $\mathrm{N}$ derived from the GM and the organic compost in the third growing cycle, due to its absorption by previous crops, associated losses (Lara Cabezas et al., 2004), and incorporation into organic forms in the soil (Amado et al., 2002; Katroschan et al., 2014). In systems of rice-wheat rotations, about $15 \%$ of the $\mathrm{N}$ from plant residues were recovered by crops, while $85 \%$ remained in the soil (Chen et al., 2010).

There was residual effect of GM doses on the maize yield (Figure 2B). With increasing doses of green fertilizer applied in broccoli crop grown previously, the maize yield was increased quadratically. The increased maize yield was obtained under the residual effect of the dose of $9 \mathrm{tha}^{-1}$ GM plus $12 \mathrm{t} \mathrm{ha}^{-1}$ compost. Silva et al. (2006) found that residual effect of $\mathrm{N}$ in the sunn hemp applied in the topping 

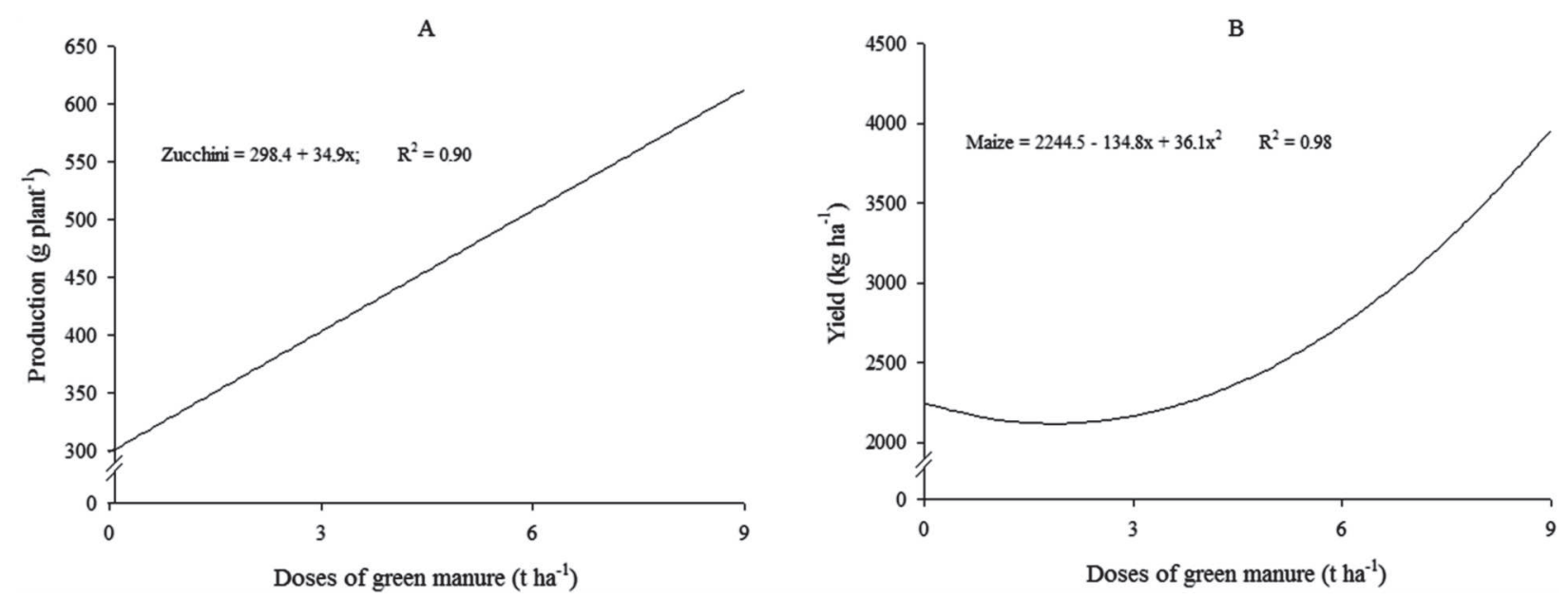

Figure 2: Residual effect of GM doses on the zucchini production (A) and maize yield (B) grown in the broccoli-zucchini-maize succession.

Table 3: Number of applied $\mathrm{N}$ in $\mathrm{kg} \mathrm{ha}^{-1}$, exported by the inflorescence of broccoli and the zucchini fruits and the final balance in the soil, in the third maize crop

\begin{tabular}{lcccc}
\hline \multirow{2}{*}{ Treatments } & Applied N & \multicolumn{2}{c}{ Exported N } & \multicolumn{2}{c}{$\begin{array}{c}\text { Final } \\
\text { Balance }\end{array}$} \\
\cline { 3 - 4 } & & Broccoli & Zucchini & -14.9 \\
AB & 0.0 & 4.6 & 10.3 & 390.9 \\
250C & 432.5 & 12.5 & 29.1 & 68.1 \\
MF & 150.0 & 39.1 & 42.8 & 174.7 \\
OGM + 120C & 207.6 & 12.1 & 20.8 & 219.4 \\
3GM + 120C & 264.3 & 17.3 & 27.6 & 267.1 \\
6GM + 120C & 321.0 & 19.4 & 34.5 & 308.1 \\
9GM + 120C & 377.7 & 28.2 & 41.4 & \\
\hline
\end{tabular}

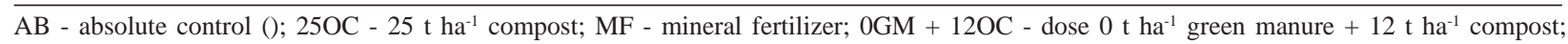
$3 \mathrm{GM}+12 \mathrm{OC}-$ dose $3 \mathrm{tha}^{-1}$ green manure $+12 \mathrm{tha}^{-1}$ compost; $6 \mathrm{GM}+12 \mathrm{OC}-$ dose $6 \mathrm{tha}^{-1}$ green manure $+12 \mathrm{tha}^{-1}$ compost; $9 \mathrm{GM}+12 \mathrm{OC}$ - dose $9 \mathrm{t} \mathrm{ha}^{-1}$ green manure $+12 \mathrm{t} \mathrm{ha}^{-1}$ compost.

of the previous year, resulted in maize yield ranging from 6,129 to $5,012 \mathrm{~kg} \mathrm{ha}^{-1}$. The authors reported a high permanence of $\mathrm{N}$ in soil and that the response to the residual effect depends mainly on weather conditions, growing system, crop management, and characteristics of the residue.

\section{CONCLUSIONS}

There was a residual effect of Crotalaria juncea mass, which was applied in broccoli crop for the growth and yield of zucchini and, as a result, maize yield in succession.

The residual effect was dependent on the amount of mass of $C$. juncea applied, with the greatest effects in larger doses.

\section{ACKNOWLEDGEMENTS}

The authors thank the Fundação de Amparo à Pesquisa do Estado de Minas Gerais (FAPEMIG) and the Conselho Nacional de Desenvolvimento Científico e Tecnológico (CNPq) for financial support.

\section{REFERENCES}

Alves BJR, Lincoln Z, Fernandes FM, Heckler JC, Macedo RAT, Boddey RM, Jantalia CP \& Urquiaga S (2006) Fixação biológica de nitrogênio e fertilizantes nitrogenados no balanço de nitrogênio em soja, milho e algodão. Pesquisa Agropecuária Brasileira, 41:449-456.

Amado TJC, Mielniczuk J \& Aita C (2002) Recommendation of nitrogen fertilization for no-till corn in RS and SC, adapted to the use of soil cover crops. Revista Brasileira de Ciência do Solo, 26:241-248.

Camargo Filho WP \& Camargo FP (2008) Planejamento da produção sustentável de hortaliças folhosas: organização das informações decisórias ao cultivo. Informações Econômicas, 38:27-36.

Castro MCD, Alves BJR, Almeida DJ \& Ribeiro RLD (2004) Adubação verde como fonte de nitrogênio para a cultura da berinjela em sistema orgânico. Pesquisa Agropecuária Brasileira, 39:779785 .

Chen Y, Wu C, Tang X, Yang S \& Wang J (2010) Fate of nitrogen from organic and inorganic sources in rice-wheat rotation cropping system. Agricultural Sciences in China, 9:1017-1025.

Diniz ER, Santos RHS, Urquiaga SS, Peternelli LA, Barrella TP \& Freitas GB (2007) Green manure incorporation timing for organically grown broccoli. Pesquisa Agropecuária Brasileira, 42:199-206. 
Diniz ER, Santos RHS, Urquiaga SS, Peternelli LA, Barrella TP \& Freitas GB (2008) Crescimento e produção de brócolis em sistema orgânico em função de doses de composto. Ciência e Agrotecnologia, 32:1428-1434.

Diniz ER, Vargas TO, Pereira WD, Guedes AF, Santos RHS \& Peternelli LA (2014) Decomposição e mineralização do nitrogênio proveniente do adubo verde Crotalaria juncea. Científica, 42:51-59.

Figueiredo CC, Resck DVS, Gomes AC \& Urquiaga S (2005) Sistemas de manejo na absorção de nitrogênio pelo milho em um Latossolo Vermelho no Cerrado. Pesquisa Agropecuária Brasileira, 40:279-287.

Frighetto RTS \& Valarini PJ (2000) Indicadores biológicos e bioquímicos da qualidade do solo: manual técnico. Jaguariúna, Embrapa Meio Ambiente. 198p.

Lange A, Lara-Cabezas WAR \& Trivelin PCO (2008) Recuperação do nitrogênio das fontes sulfato e nitrato de amônio pelo milho em sistema semeadura direta. Pesquisa Agropecuária Brasileira, 43:123-130.

Lara Cabezas WRL, Alves BJR, Urquiaga S \& Santana DG (2004) Influence of the previous winter crop and nitrogen fertilization to corn productivity in no-tillage and conventional tillage. Ciência Rural, 34:1005-1013.

Lúcio AD, Carpes RH, Storck L, Lopes SJ, Lorentz LH \& Paludo AL (2008) Variância e média da massa de frutos de abobrinhaitaliana em múltiplas colheitas. Horticultura Brasileira, 26:335341.

Katroschan KU, Uptmoor R \& Stutzel H (2014) Nitrogen use efficiency of organically fertilized white cabbage and residual effects on subsequent beetroot. Plant and Soil, 382:237-251.

Marchi ECS, Alvarenga M, Marchi G, Silva CA \& Filho JLS (2008) Efeito da adubação orgânica sobre as frações de carbono de solos cultivados com alface americana. Ciência e Agrotecnologia, 32:1760-1766.

Matos ES, Mendonça ES, Lima PC, Coelho MS, Mateus RF \& Cardoso IM (2008) Green manure in coffee systems in the region of Zona da Mata, Minas Gerais: characteristics and kinetics of carbon and nitrogen mineralization. Revista Brasileira de Ciência do Solo, 32:2027-2035.
Oliveira FL, Ribas RGT, Junqueira RM, Padovan MP, Guerra JGM, Almeida DL \& Ribeiro RLD (2003) Uso do pré-cultivo de Crotalaria juncea e de doses crescentes de "cama" de aviário na produção do repolho sob manejo orgânico. Agronomia, 37:6066

Oliveira FL, Ribas RGT, Junqueira RM, Padovan MP, Guerra JGM, Almeida DL \& Ribeiro RLD (2005) Desempenho do consórcio entre repolho e rabanete com pré-cultivo de crotalária, sob manejo orgânico. Horticultura Brasileira, 23:184-188.

Perin A, Santos RHS, Caballero SSU, Guerra JGM \& Gusmão LA (2010) Acúmulo e liberação de $\mathrm{P}, \mathrm{K}, \mathrm{Ca}$ e Mg em crotalária e milheto solteiro e consorciados. Revista Ceres, 57:274-281.

Scivittaro WB, Muraoka T, Boaretto AE \& Trivelin PCO (2003) Transformations of nitrogen from velvet bean and urea used as fertilizers in corn crop. Pesquisa Agropecuária Brasileira, 38:1427-1433.

Silva JAA, Vitti GC, Stuchi ES \& Sempionato OR (2002) Reciclagem e incorporação de nutrientes ao solo pelo cultivo intercalar de adubos verdes em pomar de laranjeira-"Pêra". Revista Brasileira de Fruticultura, 24:225-230.

Silva EC, Muraoka T, Buzetti S \& Trivelin PCO (2006) Manejo de nitrogênio no milho em Latossolo Vermelho sob plantio direto com diferentes plantas de cobertura. Pesquisa Agropecuária Brasileira, 41:477-486.

Tedesco MJ, Gianello C, Bissani CA, Bohnen H \& Volkeiss SJ (1995) Análise de solo, plantas e outros materiais. Porto Alegre, UFRGS. 174p.

Vargas TO, Diniz ER, Santos RHS, Lima CTA, Urquiaga S \& Cecon PR (2011) Influência da biomassa de leguminosas sobre a produção de repolho em dois cultivos consecutivos. Horticultura Brasileira, 29:562-568.

Vilela EF, Freitas MRC, Piano PB, Santos RHS \& Mendonça ES (2011) Crescimento inicial de cafeeiros e fertilidade do solo adubado com mucuna, amendoim forrageiro ou sulfato de amônio. Coffee Science, 6:27-35. 